\title{
Pengaruh Agresivitas Pelaporan Keuangan terhadap Agresivitas Pajak: Dampak Penerapan Mandatory Disclosure Rules (Studi pada Negara- negara Anggota G-20)
}

Authors:

Reza Regia Sugandi ${ }^{1}$

Ida Farida Adi Prawira ${ }^{2}$

\section{Affiliations:}

${ }^{1,2}$ Program Studi Akuntansi, Fakultas Pendidikan Ekonomi dan Bisnis, Universitas Pendidikan Indonesia, Bandung, Indonesia

Corresponding Author: Ida Farida Adi Prawira

\section{Emails:}

'zaregia91@gmail.com 2ida.farida@upi.edu

\section{Article History:}

Received: February 1, 2019

Revised : April 4, 2019

Accepted: June 17, 2019

How to cite this article: Sugandi, R. R., \& Prawira, I. F. A. (2019). Pengaruh Agresivitas Pelaporan Keuangan terhadap Agresivitas Pajak: Dampak Penerapan Mandatory Disclosure Rules (Studi pada Negara-negara Anggota G-20). Organum: Jurnal Saintifik Manajemen dan Akuntansi, 2(1), 12-24. doi: https://doi.org/10.35138/organu $\underline{\text { m.v2i1.55 }}$

Journal Homepage: ejournal.winayamukti.ac.id/ind ex.php/Organum

\section{Copyright:}

(C) 2019. Published by Organum: Jurnal Saintifik Manajemen dan Akuntansi. Faculty of Economics and Business. Winaya Mukti University.
Abstract. This study aims to examine the effect of the aggressiveness of financial reporting on tax aggressiveness behavior and examine the differences in tax aggressiveness behavior between before and after the implementation of mandatory disclosure rules. This study used data sourced from the financial statements of companies listed on investing.com for the 2016-2017 period. The samples used were 54 companies. The data analysis method used descriptive statistical analysis using panel data regression. The results showed that the aggressiveness of financial reporting affected the tax aggressiveness and there was no difference in the behavior of tax aggressiveness between before and after the implementation of mandatory disclosure rules.

Keywords: Accrual discretion; effective tax rate; tax aggressiveness; earning management; mandatory disclosure rules.

\begin{abstract}
Abstrak. Penelitian ini bertujuan untuk meneliti pengaruh agresivitas pelaporan keuangan terhadap perilaku agresivitas pajak serta meneliti perbedaan perilaku agresivitas pajak antara sebelum dan sesudah penerapan Mandatory Disclosure Rules. Penelitian ini menggunakan data yang bersumber dari laporan keuangan perusahaan yang terdaftar di investing.com periode 2016-2017. Sampel yang digunakan sebanyak 54 perusahaan. Metode penelitian yang digunakan adalah analisis deskriptif dan verifikatif, dan data diolah dengan menggunakan regresi data panel. Hasil penelitian menunjukkan bahwa agresivitas pelaporan keuangan berpengaruh terhadap agresivitas pajak dan tidak terdapat perbedaan perilaku agresivitas pajak antara sebelum dan sesudah penerapan Mandatory Disclosure Rules.
\end{abstract}

Kata Kunci: Diskresi akrual; effective tax rate; agresivitas pajak; manajemen laba; mandatory disclosure rules.

\section{Pendahuluan}

$\mathrm{P}$ ajak merupakan roda penggerak ekonomi utama di Indonesia, sehingga dalam pemungutannya bersifat wajib serta memaksa bagi seluruh wajib pajak yang telah diatur dalam undang-undang. Selain sebagai wujud kepatuhan terhadap negara, pajak juga menjadi sumber penerimaan utama yang sangat strategis dan andal bagi pelaksanaan pembangunan nasional. Data APBN tahun 2018 menyebutkan bahwa pajak menyumbang sebesar Rp 1.618,1 triliun atau sekitar 85\% dari total pendapatan negara (www.kemenkeu.go.id). Hal ini tidak terlepas dari peran pemerintah yang selalu berupaya untuk memaksimalkan pemasukan pajak melalui penerapan kebijakan 
perpajakan. Akan tetapi perusahaan selaku wajib pajak menganggap pajak sebagai suatu beban, oleh karenanya perusahaan akan berusaha untuk meminimalkan pembayaran pajak. Salah satu upaya yang dilakukan perusahaan dalam mengatasi pembayaran pajak adalah dengan meminimalkan pajak melalui perilaku agresivitas pajak.

Frank et al. (2009) mendefinisikan pajak agresif sebagai suatu kegiatan perusahaan dalam menurunkan laba kena pajak melalui perencanaan pajak, baik menggunakan cara yang tergolong ataupun tidak tergolong tax evasion. Akan tetapi kegiatan ini dapat merugikan perusahaan, dengan menurunkan laba investor dan kreditor akan menilai buruk kinerja ekonomi suatu perusahaan karena hanya memiliki sedikit laba. Sedangkan, perusahaan memiliki kecendrungan untuk meningkatkan laba guna mendapatkan investasi ataupun pinjaman. Kecenderungan ini sering disebut sebagai agresivitas pelaporan keuangan. Agresivitas pelaporan keuangan adalah usaha perusahaan dalam meningkatkan laba yang dimilikinya melalui earning management yang sesuai ataupun tidak sesuai dengan aturan akuntansi yang berlaku (Frank et al., 2009).

Hubungan yang terjadi antara agresivitas pajak dan pelaporan keuangan yang dilakukan perusahaan akan memunculkan suatu trade-off. Dengan demikian, perusahaan berani membayar pajak lebih demi memunculkan laporan laba yang lebih tinggi kepada stakeholder (Erickson et al., 2004). Namun, dewasa ini trade-off yang terjadi antara pajak dan pelaporan keuangan tidak selalu terjadi. Pada kenyataannya banyak sekali perusahaan yang melaporkan laba yang tinggi kepada stakeholder, namun membayar beban pajak dengan biaya yang rendah kepada otoritas perpajakan. Pada tahun 90-an penelitian di Amerika membuktikan bahwa tindakan agresivitas pajak mulai rutin menyertai agresivitas pelaporan keuangan (Lennox et al., 2013;
Prawira \& Setiawan, 2018). Kondisi ini berdampak pada terus meningkatnya Book Tax Difference. Frank et al (2009) menyebutkan peningkatan yang terjadi terhadap Book Tax Difference disinyalir akibat adanya loopholes antara prinsip akuntansi dan aturan perpajakan. Peluang yang muncul akibat terjadinya loopholes sering dimanfaatkan perusahaan dengan cara melakukan tax planning.

Adanya permasalahan ini membuat dunia internasional geram khususnya bagi Organisation for Economic Co-operation and Development (OECD). Dalam mengatasi hal tersebut OECD bekerjasama dengan G-20 dan berhasil merumuskan aturan yang diberi nama Global Action Plan (OECD, 2013a, 2013b). Salah satu bagian dari rencana tersebut yaitu Action 12 berbunyi "require taxpayer to disclose their aggressive tax palnning arrangements". Dari action ini, wajib pajak diharuskan untuk mengungkapkan perencanaan pajak mereka yang bersifat agresif menggunakan suatu kebijakan yang disebut dengan Mandatory Disclosure Rules (MDR). Adapun negara G-20 yang telah menerapkan aturan MDR antara lain Amerika Serikat, Kanada, Afrika Selatan, Inggris, Portugal, Irlandia, Israel, dan Korea. Di Indonesia sendiri, pembahasan mengenai MDR mulai hangat diperbincangkan sejak Februari 2018 dan pemerintah Indonesia mulai mempersiapkan rancangan peraturan perpajakan baru terkait Mandatory Disclosure Rules.

Penelitian mengenai hubungan antara agresivitas pajak dan agresivitas pelaporan keuangan telah diteliti sebelumnya oleh Erickson et al. (2004), hasil penelitiannya menyebutkan bahwa perusahaan akan mengalami trade-off antara pajak dan besaran laba. Akan tetapi, hasil penelitian terkini menyebutkan bahwa tidak adanya trade-off yang dialami perusahaan. Hal tersebut dibuktikan oleh Frank et al. (2009) di Amerika Serikat yang meneliti agresivitas 
pajak dan pelaporan keuangan, hasil penelitian disebutkan bahwa terdapat hubungan positif dan signifikan antara pajak agresif dan pelaporan keuangan. Kemudian dipertegas oleh Lennox et al. (2013) yang menyebutkan bahwa tindakan agresivitas pajak mulai rutin menyertai kegiatan agresivitas pelaporan keuangan. Di Indonesia (Kamila, 2014; Prawira \& Setiawan, 2018) telah menganalisis hubungan antara agresivitas pajak dan agresivitas pelaporan keuangan. Hasil yang didapat dari penelitian tersebut yaitu adanya hubungan positif antara keduanya.

Berdasarkan fenomena yang telah dipaparkan dan adanya gap dari hasil penelitian terdahulu, maka peneliti tertarik untuk melakukan penelitian ulang terkait agresivitas pajak dengan memperbaharui sampel penelitian, metode penelitian, rentang tahun, dan penambahan fenomena MDR. Dampak penerapan Mandatory Diclosure Rules ini penting untuk diteliti karena kebijakan ini baru saja dikeluarkan dan belum pernah ada yang meneliti sebelumnya. Lebih lanjut, penelitian ini memasukan variabel kontrol yang menurut Kamila (2014) dapat memengaruhi kuat lemahnya perilaku agresivitas pajak suatu perusahaan yang diantaranya Pretax Return on Asset, Loss Carry Forward, kawasan operasi perusahaan, Leverage, dan ukuran perusahaan.

\section{Kajian Literatur}

Anthony \& Govindarajan (2005:269) menyatakan bahwa hubungan agensi terjadi ketika salah satu pihak (principal) menyewa pihak lain (agent) untuk melaksanakan suatu jasa dan mendelegasikan wewenang untuk membuat keputusan kepada agent tersebut. Hal ini dapat menyebabkan ketidakseimbangan informasi (asymmetry information) antara principal dan agent. Bahwasanya agent sebagai pelaksana memiliki lebih banyak informasi mengenai perusahaan jika dibandingkan dengan principal yang hanya memiliki sedikit informasi mengenai perusahaan. Hal inilah yang terkadang menyebabkan adanya kebijakan-kebijakan tertentu yang hanya diketahui oleh agent, sedangkan principal tidak mengetahuinya.

\section{Agresivitas Pajak}

Agresivitas pajak adalah kegiatan yang ditujukan untuk menurunkan laba kena pajak melalui perencanaan pajak (Frank et al., 2009). Besarnya beban pajak yang harus ditanggung membuat perusahaan cenderung untuk meminimalkan beban pajak tersebut melalui berbagai cara guna meningkatkan nilai perusahaan itu sendiri. Tindakan atau upaya meminimalkan beban pajak nantinya dapat menghasilkan pelaporan pajak agresif (Hanlon \& Slemrod, 2009; Desai \& Dharmapala, 2009; Chen et al., 2010).

\section{Agresivitas Pelaporan Keuangan}

Agresivitas pelaporan keuangan adalah kegiatan meningkatkan laba perusahaan melalui Earning management, baik sesuai atau tidak sesuai dengan prinsip akuntansi yang berlaku (Ewert \& Wagenhofer, 2005; Frank et al., 2009). Earning management terjadi saat manajer menggunakan pendapat mereka dalam menyusun laporan keuangan perusahaan dan mengelola transaksi yang terjadi sehingga merubah laporan keuangan yang seharusnya, baik untuk menyesatkan stakeholder ataupun memengaruhi pengguna laporan keuangan lainnya yang hanya bergantung pada angka-angka yang tercantum dalam laporan keuangan (Healy dan Wahlen, 1999; Prawira, 2017; Prawira, 2017).

\section{Pretax Return on Asset (PTROA)}

PTROA merupakan proksi profitabilitas yang mengukur kemampuan perusahaan dalam mendayagunakan aset yang dimilikinya untuk memperoleh laba sebelum pajak. Apabila rasio profitabilitas suatu perusahaan tinggi, berarti menunjukkan adanya efisiensi yang dilakukan oleh pihak manajemen. Laba yang meningkat mengakibatkan profitabi- 
litas perusahaan juga meningkat, peningkatan laba mengakibatkan jumlah pajak yang harus dibayar juga semakin besar, jika jumlah pajak yang harus dibayar meningkat maka aset yang digunakan untuk membayar pajak akan ikut tinggi. Perusahaan yang memiliki tingkat profitabilitas tinggi memiliki kesempatan untuk melakukan upaya efisiensi dalam kewajiban pembayaran pajak melalui perilaku agresivitas pajak. Sebaliknya, apabila nilai Pretax Return on Asset semakin rendah yang berdampak pada semakin rendahnya produktivitas aset dan tingkat profitabilitas perusahaan menyebabkan perusahaan tidak memiliki kesempatan untuk melakukan upaya efisiensi dalam hal pembayaran kewajiban pajak melalui perilaku agresivitas pajak (Chen et al., 2010). Pernyataan tersebut sesuai dengan penelitian Frank et al. (2009) Prawira dan Setyawan (2018) yang menyebutkan bahwa Pretax Return on Asset berpengaruh signifikan terhadap perilaku agresivitas pajak. Diukur dari hasil bagi antara pendapatan sebelum pajak dengan total asset.

\section{Leverage (LEV)}

LEV menurut Sartono (2008:257)

Leverage atau solvabilitas merupakan suatu ukuran seberapa besar aset yang dimiliki perusahaan yang dibiayai oleh hutang. Metode pembiayaan perusahaan melalui kebijakan hutang dan struktur modal merupakan diskresi dari manajer perusahaan untuk memilih pendanaan dengan menggunakan utang atau modal, hal ini tidak mengharuskan keterlibatan investor dalam pengambilan keputusan tersebut. Apabila manajer memilih metode pembiayaan melalui kebijakan hutang maka akan berdampak pada beban pajak. Penambahan sejumlah hutang suatu perusahaan akan menimbulkan beban bunga yang menjadi pengurang beban pajak perusahaan (Kurniasih \& Sari, 2013). Beban bunga yang timbul atas hutang yang dimiliki perusahaan akan menjadi pengurang laba bersih perusahaan yang nantinya akan mengurangi pembayaran pajak sehingga tercapainya keuntungan yang maksimal. Pernyataan ini didukung oleh penelitian terdahulu salah satunya Nurhandono \& Firmansyah (2017) yang membuktikan bahwa Leverage memiliki pengaruh signifikan terhadap perilaku agresivitas pajak dan perusahaan yang memiliki rasio Leverage yang tinggi mengakibatkan beban bunga dari hutang tersebut juga akan meningkat, dari tingginya beban bunga yang ditanggung oleh perusahaan dapat dimanfaatkan sebagai pengurang laba kena pajak agar pajak terungan semakin rendah dan pembayaran pajak semakin kecil. Sedangkan hasil tersebut bertolak belakang dengan penelitian Kamila (2014) yang menyebutkan bahwa Leverage tidak berpengaruh terhadap agresivitas pajak. Kamila (2014) berpendapat bahwa terdapat perbedaan aturan pajak di setiap negara mengenai pembebanan bunga, sehingga tidak seluruh beban bunga dapat menjadi pengurang bagi beban pajak. Diukur dari hasil bagi antara total hutang dengan total aset.

\section{Loss Carry Forward (LCF_D)}

Loss Carry Forward mengacu pada teknik akuntansi yang menerapkan rugi operasi bersih (NOL) tahun berjalan ke laba bersih tahun-tahun mendatang untuk mengurangi kewajiban pajak. Jika perusahaan mengalami pendapatan operasional bersih negatif (NOI) di tahun pertama, tetapi positif NOI di tahun-tahun berikutnya, itu dapat mengurangi jumlah laba di masa depan yang dilaporkan menggunakan carry NOL untuk mencatat sebagian atau semua kerugian dari tahun pertama ke tahun-tahun berikutnya. Hal ini menghasilkan pendapatan kena pajak yang lebih rendah pada tahun-tahun dengan NOI positif, dan mengurangi jumlah utang perusahaan kepada pemerintah. Hal ini didukung oleh hasil penelitian Frank et al., (2009) dan Kamila (2014) yang menyebutkan bahwa Loss Carry Forward berpengaruh signifikan terhadap agresivitas pajak suatu perusahaan. Diukur dengan variabel 
dummy, diberi nilai 1 jika perusahaan memiliki Loss Carry Forward dan 0 jika sebaliknya.

\section{Kawasan Operasi Perusahaan (FOR_D)}

FOR_D merupakan gambaran yang menunjukkan kegiatan perusahaan di luar Negeri. Kegiatan ini dapat mengindikasikan perusahaan dalam melakukan pemindahkan kekayaan yang dimiliki negara dengan tarif pajak rendah (tax shifting). Hal ini didukung oleh penelitian Kamila (2014) yang menyebutkan bahwa kawasan operasi perusahaan berpengaruh signifikan terhadap agresivitas pajak. Hal ini akan diukur dengan menggunakan variabel dummy, diberi nilai 1 jika perusahaan memiliki operasi di luar negeri dan 0 jika sebaliknya.

\section{Ukuran Perusahaan (SIZE)}

Semakin besar ukuran perusahaan yang dilihat dari total aset yang dimiliki maka semakin rentan pula terhadap praktik penghindaran pajak karena manajemen perusahaan akan berusaha menjaga stabilitas tingkat laba guna meminimalisasi pengeluaran untuk pajak. Saat perusahaan telah mampu menghasilkan laba sebelum pajak yang tinggi, maka akan timbul keinginan untuk menekan jumlah beban pajak yang harus dibayar agar laba setelah pajak dapat maksimal. Karena sejatinya tidak ada perusahaan yang secara sukarela ingin membayarkan dananya untuk kebutuhan pajak kepada negara. Pengeluaran pajak yang dilakukan perusahaan berdampak pada pengurangan jumlah aset sehingga hal ini akan memengaruhi kegiatan operasional perusahaan. Untuk mengatasi risiko ini perusahaan cenderung untuk melakukan agresivitas pajak agar jumlah pembayaran pajak yang dikeluarkan menjadi minimal. Hal ini didukung oleh Diawati (2017) yang menyatakan bahwa ukuran perusahaan berpengaruh signifikan terhadap agresivitas pajak.
Diukur dengan menggunakan logaritma natural dari total aset perusahaan.

\section{Pengaruh Agresivitas Pelaporan Keuangan terhadap Agresivitas Pajak}

Perusahaan selaku wajib pajak seringkali tidak mematuhi ketentuan perpajakan yang berlaku demi melakukan penghematan pajak. Terlebih lagi dengan adanya agency problem yang mampu memicu dilakukannya penghematan pajak. Menurut Kamila (2014) hubungan antara pajak agresif dan pelaporan keuangan dapat bersifat resiprokal atau dua arah. Dengan kata lain manajeman pajak dapat memengaruhi tindakan manajemen laba begitu pula manajemen laba dapat memengaruhi manajemen pajak yang dilakukan perusahaan. Hal ini dapat dilihat pada alasan dan motivasi dilakukannya manajemen laba dan manajemen pajak yang relatif sama. Manajemen pajak dikatakan mampu memengaruhi manajemen laba karena salah satu upaya yang dilakukan dalam manajemen laba adalah pengendalian beban perusahaan, dan salah satunya adalah beban pajak.

$\mathrm{H}_{1}=$ Agresivitas pelaporan keuangan berpengaruh terhadap agresivitas pajak.

\section{Mandatory Disclosure Rules}

Mandatory Disclosure Rules (MDR) merupakan aturan perpajakan yang mengharuskan perusahaan selaku wajib pajak beserta promotornya (konsultan pajak, penasehat keuangan, law firm) untuk melaporkan skema tax planning yang digunakan. Peraturan MDR diterapkan telebih dahulu di 8 negara G20 yaitu Amerika Serikat, Kanada, Inggris, Irlandia, Portugal, Afrika Selatan, Israel, dan Korea. OECD mengatakan bahwa penerapan aturan MDR di negara tersebut berhasil dalam penurunan perilaku agresivitas pajak yang dilakukan oleh perusahaan (OECD, 2015).

$\mathrm{H}_{1}=$ Terdapat perbedaan perilaku agresivitas pajak antara sebelum dan sesu- 
dah penerapan Mandatory Disclosure Rules.

\section{Metode Penelitian}

Penelitian ini menggunakan pendekatan kuantitatif dengan metode deskriptif dan verifikatif. Populasi penelitian ini adalah perusahaan manufaktur di negara G-20 periode tahun 2016-2017. Metode pengambilan sampel yang digunakan adalah nonprobability sampling dengan teknik purposive sampling yang merupakan teknik penentuan sampel dengan pertimbangan tertentu (Sugiyono, 2018:85, Basuki \& Prawoto, 2016; Sekaran, 2014). Berdasarkan kriteria sampel yang telah ditentukan terdapat 54 perusahaan manufaktur yang akan dijadikan sampel penelitian. Jenis data yang digunakan adalah data sekunder yaitu dari laporan tahunan dan laporan keuangan yang diperoleh dari situs www.investing.com.

Teknik analisis data dalam penelitian ini menggunakan statistik deskriptif dan regresi data panel untuk menganalisis variabel agresivitas pelaporan keuangan (X) terhadap agresivitas pajak (Y). Selain itu dilakuakan uji beda t-test sampel independen untuk mengukur perbedaan perilaku agresivitas pajak antara sebelum dan sesudah penerapan Aturan Mandatory Disclosure Rules. Alat pengolahan data yang digunakan adalah Software Microsoft Excel dan aplikasi Eviews 10.

\section{Variabel dan Pengukuran} Agresivitas Pajak

Agresivitas pajak diukur menggunakan proksi Effective Tax Rate (ETR) dengan membandingkan beban pajak terhadap laba sebelum pajak (Hanlon \& Heitzman, 2010).

$$
\mathrm{ETR}=\frac{\text { Tax expense }}{\text { Pre tax income }}
$$

\section{Agresivitas Pelaporan Keuangan}

Agresivitas pelaporan keuangan dihitung menggunakan proksi diskresi akrual yang dapat dihitung dengan menggunakan Modified-Jones Model yang dimodifikasi (Dechow et al., 1995). Alasan penggunaan model ModifiedJones karena merupakan model terbaik dalam hal mendeteksi manejemen laba dan telah banyak dipakai luas oleh peneliti sebelumnya.

$$
\begin{gathered}
\text { TACC }_{i t}=a_{0}+\beta_{1}\left(\Delta \mathrm{REV}_{\mathrm{it}}-\Delta \mathrm{AR}_{i t}\right) \\
+\beta_{2} \mathrm{PPE}_{i t}+\varepsilon_{i t}
\end{gathered}
$$

\section{Pretax Return on Asset}

Pretax Return on Asset merupakan variabel kontrol yang diukur dengan membandingkan pendapatan sebelum pajak terhadap total asset.

$$
\text { PTROA }=\frac{\text { Pre tax income }}{\text { Total asset }}
$$

\section{Leverage}

Leverage merupakan variabel
kontrol yang diukur
membandingkan total hutang
tengan
total aset.

$$
\mathrm{LEV}=\frac{\text { Total hutang }}{\text { Total aset }}
$$

\section{Loss Carry Forward}

Loss Carry Forward merupakan variabel kontrol yang diukur menggunakan variabel dummy, jika perusahaan memiliki Loss Carry Forward diberi nilai 1 dan jika perusahaan tidak memiliki Loss Carry Forward diberi nilai 0 .

\section{Kawasan Operasi Perusahaan}

Kawasan operasi perusahaan merupakan variabel kontrol yang diukur menggunakan variabel dummy, jika perusahaan memiliki operasi di luar negeri maka diberi nilai 1 dan jika perusahaan tidak memiliki operasi di luar negeri diberi nilai 0 .

\section{Ukuran Perusahaan}

Ukuran perusahaan merupakan variabel kontrol yang diukur menggunakan logaritma normal dari total asset. LN Total Asset 


\section{Hasil dan Pembahasan}

\section{Regresi Data Panel}

\section{Pemilihan Model Regresi Data Panel}

Uji Lagrange Multiplier digunakan untuk memilih model terbaik antara
Random Effect Model dengan Common Effect Model. Uji Lagrange Multiplier merupakan pengujian terakhir setelahan sebelumnya dilakukan uji chow dan uji hausman. Adapun hasil uji Lagrange Multipier disajikan dalam Tabel 1.

Tabel 1. Uji Lagrange Multiplier

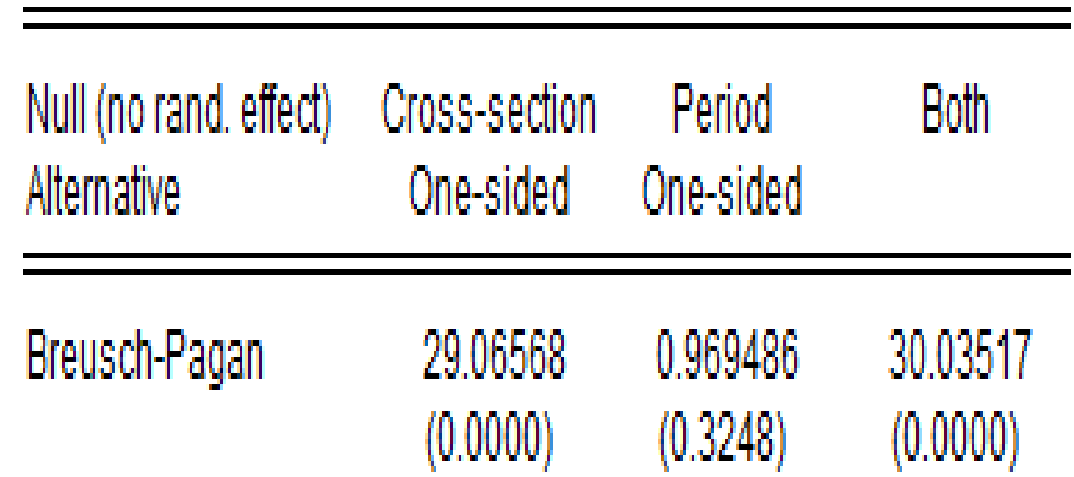

Sumber: Output Eviews 10

Berdasarkan Tabel 1 hasil uji Lagrange Multiplier penelitian agresivitas pelaporan keuangan terhadap agresivitas pajak menghasilkan nilai Cross-section Breusch-Pagan sebesar 0,0000 yaitu lebih kecil dari alpha 0,05 sehingga $\mathrm{H}_{0}$ diterima. Sesuai dengan kriteria keputusan dalam uji Lagrange multiplier maka model yang sesuai adalah Random Effect
Model. Model kemudian di uji asumsi klasik dan mengalami masalah heterokedestisitas setelah diuji Modified Wald Test. Permasalahan diatasi dengan menggunakan metode pembobotan (weighted). Model terbebas dari autokolerasi dan multikolienaritas.

\section{Pengujian Hipotesis}

\section{Tabel 2. Hasil Regresi Data Panel}

\begin{tabular}{|c|c|c|c|c|}
\hline \multicolumn{5}{|c|}{$\begin{array}{l}\text { Dependent Variable: Y } \\
\text { Method: Panel EGLS (Cross-section weights) } \\
\text { Date: 08/14/19 Time: } 12: 00 \\
\text { Sample: } 20162017 \\
\text { Periods included: } 2 \\
\text { Cross-sections included: } 54 \\
\text { Total panel (balanced) observations: } 108 \\
\text { Linear estimation after one-step weighting matrix }\end{array}$} \\
\hline Variable & Coefficient & Std. Error & t-Statistic & Prob. \\
\hline $\begin{array}{l}C \\
X 1 \\
X 2 \\
X 3 \\
X 4 \\
X 5 \\
X 6\end{array}$ & $\begin{array}{r}0.400762 \\
-0.220653 \\
0.182747 \\
0.084174 \\
0.036444 \\
-0.023734 \\
0.005681\end{array}$ & $\begin{array}{l}0.029492 \\
0.102424 \\
0.060401 \\
0.120312 \\
0.009530 \\
0.009398 \\
0.001870\end{array}$ & $\begin{array}{r}13.58871 \\
-2.154324 \\
3.025561 \\
0.699634 \\
3.824011 \\
-2.525461 \\
3.038667\end{array}$ & $\begin{array}{l}0.0000 \\
0.0336 \\
0.0031 \\
0.4858 \\
0.0002 \\
0.0131 \\
0.0030\end{array}$ \\
\hline \multicolumn{5}{|c|}{ Weighted Statistics } \\
\hline $\begin{array}{l}\text { R-squared } \\
\text { Adjusted R-squared } \\
\text { S.E. of regression } \\
\text { F-statistic } \\
\text { Prob(F-statistic) }\end{array}$ & $\begin{array}{l}0.300322 \\
0.258757 \\
0.121834 \\
7.225351 \\
0.000002\end{array}$ & \multicolumn{2}{|c|}{$\begin{array}{l}\text { Mean dependentvar } \\
\text { S.D. dependent var } \\
\text { Sum squared resid } \\
\text { Durbin-Watson stat }\end{array}$} & $\begin{array}{l}1.062412 \\
0.952025 \\
1.499208 \\
0.961359\end{array}$ \\
\hline \multicolumn{5}{|c|}{ Unweighted Statistics } \\
\hline $\begin{array}{l}\text { R-squared } \\
\text { Sum squared resid }\end{array}$ & $\begin{array}{l}0.065325 \\
1.617984\end{array}$ & $\begin{array}{l}\text { Mean depender } \\
\text { Durbin-Watson }\end{array}$ & $\begin{array}{l}\text { entvar } \\
\text { n stat }\end{array}$ & $\begin{array}{l}0.517778 \\
0.505589\end{array}$ \\
\hline
\end{tabular}

Sumber: Output Eviews 10 
Berdasarkan Tabel 2 dapat dirumuskan persamaan regresi data panel sebagai berikut.

$$
\begin{aligned}
& \mathrm{AP}=0,401-0,221 \mathrm{APK}+ \\
& 0,183 \text { PTROA }+0,084 \mathrm{LEV}+ \\
& 0,036 \mathrm{LCF} \_\mathrm{D}-0,023 \text { FOR_D + } \\
& 0,006 \text { SIZE }+\varepsilon_{i t}
\end{aligned}
$$

Keterangan:

$\begin{array}{ll}\text { AP } & \text { Agresivitas Pajak } \\ \text { APK } & =\text { Agresivitas Pelaporan } \\ & \text { Keuangan } \\ \text { PTROA } & =\text { Pretax Return on Asset } \\ \text { LEV } & =\text { Leverage } \\ \text { LCF_D } & =\text { Loss Carry Forward } \\ \text { FOR_D } & =\text { Kawasan Operasi } \\ & \text { Perusahaan } \\ \text { SIZE } & =\text { Ukuran Perusahaan }\end{array}$

Pengaruh Agresivitas Pelaporan Keuangan terhadap Agresivitas Pajak

Hasil pengujian hipotesis pengaruh agresivitas pelaporan keuangan terhadap agresivitas pajak memperlihatkan bahwa agresivitas pelaporan keuangan berpengaruh terhadap agresivitas pajak pada perusahaan manufaktur periode tahun 2016-2017. Nilai probabilitas Agresivitas Pelaporan Keuangan (APK) sebesar 0,0336 lebih kecil dari tingkat signifikansi 5\% yang berarti hipotesis nol ditolak dan hipotesis alternatif diterima sehingga agresivitas pelaporan keuangan berpengaruh terhadap agresivitas pajak. Sedangkan nilai koefisien agresivitas pelaporan keuangan menunjukkan hasil 0,220653 nilai tersebut berarti agresivitas pelaporan keuangan mempunyai arah negatif, sehingga ketika nilai agresivitas pelaporan keuangan meningkat maka potensi terjadinya agresivitas pajak semakin menurun.

Hasil penelitian ini mendukung penelitian sebelumnya yang dilakukan oleh Frank et al. (2009) dari Amerika Serikat dan Kamila (2014) dari Indonesia yang juga memperlihatkan hubungan positif antara agresivitas pajak dan agresivitas pelaporan keuangan.

Pengaruh Profitabilitas terhadap Agresivitas Pajak
Hasil pengujian hipotesis pengaruh variabel kontrol Pretax Return on Asset terhadap agresivitas pajak memperlihatkan bahwa Pretax Return on Asset berpengaruh terhadap agresivitas pajak pada perusahaan manufaktur periode tahun 2016-2017. Nilai probabilitas Pretax Return on Asset (PTROA) sebesar 0,0031 lebih kecil dari tingkat signifikasi $5 \%$ yang berarti hipotesis nol ditolak dan hipotesis alternatif diterima sehingga Pretax Return on Asset berpengaruh terhadap agresivitas pajak. Sedangkan nilai koefisien Pretax Return on Asset menunjukkan hasil 0,182747 nilai tersebut berarti Pretax Return on Asset mempunyai arah positif, sehingga ketika nilai Pretax Return on Asset meningkat maka potensi terjadinya agresivitas pajak semakin tinggi.

Hasil penelitian ini sesuai dengan penelitian yang dilakukan sebelumnya yaitu oleh Frank et al. (2009) dan Kamila (2014) yang menyebutkan bahwa profitabilitas berpengaruh secara signifikan terhadap agresivitas pajak.

\section{Pengaruh Leverage terhadap Agresivitas Pajak}

Hasil pengujian hipotesis pengaruh variabel kontrol leverage terhadap agresivitas pajak memperlihatkan bahwa leverage berpengaruh negatif terhadap agresivitas pajak pada perusahaan manufaktur periode tahun 2016 - 2017. Nilai probabilitas leverage (LEV) sebesar 0,4858 lebih besar dari tingkat signifikasi $5 \%$ yang berarti hipotesis nol diterima dan hipotesis alternatif ditolak sehingga Leverage tidak berpengaruh terhadap agresivitas pajak. Sedangkan nilai koefisien Leverage menunjukkan hasil 0,084174 nilai tersebut berarti Leverage mempunyai arah positif, sehingga ketika nilai Leverage meningkat maka potensi terjadinya agresivitas pajak semakin tinggi.

Hasil penelitian ini mendukung penelitian yang dilakukan oleh Kamila (2014) yang menyatakan bahwa Leverage 
memiliki pengaruh negatif terhadap agresivitas pajak.

\section{Pengaruh Loss Carry Forward terhadap Agresivitas Pajak}

Hasil pengujian hipotesis pengaruh variabel kontrol Loss Carry Forward terhadap agresivitas pajak memperlihatkan bahwa Loss Carry Forward berpengaruh terhadap agresivitas pajak pada perusahaan manufaktur periode tahun 2016 - 2017. Nilai probabilitas Loss Carry Forward (LCF_D) sebesar 0,0002 lebih kecil dari tingkat signifikasi $5 \%$ yang berarti hipotesis nol ditolak dan hipotesis alternatif diterima sehingga Loss Carry Forward berpengaruh terhadap agresivitas pajak. Sedangkan nilai koefisien Loss Carry Forward menunjukkan hasil 0,036444 nilai tersebut berarti Loss Carry Forward mempunyai arah positif, sehingga ketika nilai Loss Carry Forward meningkat maka potensi terjadinya agresivitas pajak semakin tinggi.

Hasil penelitian ini sesuai dengan penelitian sebelumnya yang dilakukan oleh Frank et al. (2009) dan Kamila (2014) yang juga memperlihatkan hubungan positif signifikan antara Loss Carry Forward dan agresivitas pelaporan keuangan.

\section{Pengaruh Kawasan Operasi} Perusahaan terhadap Agresivitas Pajak Hasil pengujian hipotesis pengaruh variabel kontrol kawasan operasi perusahaan terhadap agresivitas pajak memperlihatkan bahwa kawasan operasi perusahaan berpengaruh terhadap agresivitas pajak pada perusahaan manufaktur periode tahun 2016-2017. Nilai probabilitas kawasan operasi perusahaan (FOR_D) sebesar 0,0131 lebih kecil dari tingkat signifikansi 5\% yang berarti hipotesis nol ditolak dan hipotesis alternatif diterima sehingga kawasan operasi perusahaan berpengaruh terhadap agresivitas pajak. Sedangkan nilai koefisien kawasan operasi perusahaan menunjukkan hasil $-0,023734$ nilai tersebut berarti kawasan operasi perusahaan mempunyai arah negatif, sehingga ketika nilai kawasan operasi perusahaan meningkat maka potensi terjadinya agresivitas pajak semakin menurun.

Hasil penelitian ini mendukung penelitian sebelumnya yang dilakukan oleh Frank et al. (2009) dan Kamila (2014) yang juga memperlihatkan hubungan signifikan antara kawasan operasi perusahaan dan agresivitas pelaporan keuangan.

\section{Pengaruh Ukuran Perusahaan terhadap Agresivitas Pajak}

Hasil pengujian hipotesis pengaruh variabel kontrol ukuran perusahaan terhadap agresivitas pajak memperlihatkan bahwa ukuran perusahaan berpengaruh terhadap agresivitas pajak pada perusahaan manufaktur periode tahun 2016 - 2017 . Nilai probabilitas ukuran perusahaan (SIZE) sebesar 0,0030 lebih kecil dari tingkat signifikasi 5\% yang berarti hipotesis nol ditolak dan hipotesis alternatif diterima sehingga ukuran perusahaan berpengaruh terhadap agresivitas pajak. Sedangkan nilai koefisien ukuran perusahaan menunjukkan hasil 0,001870 nilai tersebut berarti ukuran perusahaan mempunyai arah positif, sehingga ketika nilai ukuran perusahaan meningkat maka potensi terjadinya agresivitas pajak semakin tinggi.

Hasil penelitian ini konsisten dengan penelitian sebelumnya yaitu Rego (2003), Hutapea (2009), dan Kamila (2014) yang juga menunjukkan hubungan positif antara ukuran perusahaan dengan agresivitas pajak. 
Tabel 3. Independent Sample T-Test

\begin{tabular}{|c|c|c|c|c|c|c|c|c|}
\hline & & \multicolumn{7}{|c|}{ Independent Samples Test } \\
\hline & & \multicolumn{2}{|c|}{ Equality of Variances } & \multicolumn{5}{|c|}{ t-test for Equality of Means } \\
\hline & & $\mathrm{F}$ & Sig. & $t$ & df & $\begin{array}{l}\text { Sig. (2- } \\
\text { tailed) }\end{array}$ & $\begin{array}{c}\text { Mean } \\
\text { Difference }\end{array}$ & $\begin{array}{l}\text { Std. Error } \\
\text { Difference }\end{array}$ \\
\hline \multirow[t]{2}{*}{$\begin{array}{l}\text { Hasil } \\
\text { Penerapan } \\
\text { MDR }\end{array}$} & $\begin{array}{l}\text { Equal } \\
\text { variances } \\
\text { assumed }\end{array}$ & 8.455 & 0.005 & 0.521 & 70 & 0.60 & 0.0334629 & 0.0641775 \\
\hline & $\begin{array}{l}\text { Equal } \\
\text { variances } \\
\text { not } \\
\text { assumed }\end{array}$ & & & 0.402 & 26.546 & 0.69 & 0.0334629 & 0.0831720 \\
\hline
\end{tabular}

Sumber: Output SPSS 25

Pengaruh Penerapan Mandatory Disclosure Rules terhadap Agresivitas Pajak

Berdasarkan hasil Independent Sample Test yang disajikan dalam Tabel 3 diketahui bahwa rata-rata nilai AP_MDR - AP_TIMDR memiliki nilai signifikansi lebih dari $\alpha(0,604>0,05)$. Hasil ini menunjukkan bahwa tidak terdapat perbedaan yang signifikan terhadap ratarata perilaku agresivitas pajak antara sebelum penerapan Mandatory Disclosure Rules di Indonesia (AP_TIMDR) dengan sesudah penerapan aturan Mandatory Disclosure Rules di Amerika Serikat (AP_MDR).

Dari pengujian yang telah dilakukan dapat disimpulkan bahwa penerapan aturan Mandatory Disclosure Rules tidak dapat menghentikan manajemen untuk melakukan perilaku agresivitas pajak. Tidak terdapatnya perbedaan perilaku agresivitas pajak dapat disebabkan dari kurangnya partisipasi negara-negara terkait penerapan Mandatory Disclosure Rules sehingga data cenderung tidak terdapat perbedaan. Di lain sisi, perbandingan antar dua negara yang berbeda disinyalir menjadi salah satu penyebab ketidakpengaruhan data karena adanya perbedaan struktur dan metode dalam perhitungan pajak.

Penelitian ini menolak hipotesis yang telah dikembangkan bahwa terdapat perbedaan tingkat perilaku agresivitas pajak antara sebelum dan sesudah penerapan Mandatory Disclosure Rules. Hasil penelitian ini tidak sejalan dengan tujuan dari Mandatory Disclosure Rules yang tertuang dalam OECD (2015). Penelitian ini juga tidak sejalan dengan penelitian sebelumnya oleh Triyanto dan Zulvina (2017) yang menyebutkan bahwa akan terdapat perbedaan apabila terjadi penerapan Mandatory Disclosure Rules.

\section{Kesimpulan}

Agresivitas pelaporan keuangan berpengaruh negatif signifikan terhadap nilai agresivitas pajak, apabila agresivitas pajak yang di proksi melalui diskresi akrual mengalami kenaikan maka menyebabkan agresivitas pajak yang diproksi melalui ETR akan mengalami penurunan, begitu pula sebaliknya.

Dari variabel kontrol yang digunakan dalam penelitian ini, 4 dari 5 variabel berpengaruh signifikan terhadap agresivitas pajak yang diantaranya adalah Pretax Return on Asset, Loss Carry Forward, kawasan operasi perusahaan, dan ukuran perusahaan. Sedangkan variabel kontrol yang tidak berpengaruh adalah Leverage.

Tidak terdapat perbedaan yang signifikan terhadap rata-rata perilaku agresivitas pajak antara sebelum penerapan Mandatory Disclosure Rules dengan sesudah penerapan Mandatory Disclosure Rules. 
Adapun rekomendasi bagi perusahaan, lebih memperhatikan faktorfaktor terkait manajemen laba yang dapat memengaruhi nilai suatu perusahaan dalam mendapatkan investasi. Selain itu dari segi manajemen pajak yang dilakukan perlu dibenahi karena jika terlalu agresif akan berdampak pada tingkat kepercayaan masyarakat terhadap perusahaan. Bagi peneliti selanjutnya, diharapkan dapat melakukan penelitian lebih lanjut dengan mengganti proksi agresivitas pajak seperti diskresi permanen, Cash ETR dan BTD. Selain itu diharapkan bagi peneliti selanjutnya dapat meneliti penerapan Mandatory Disclosure Rules secara real di Indonesia.

\section{Daftar Pustaka}

Anthony, R. N., \& Govindarajan, V. (2005). Sistem Pengendalian Manajemen. Jakarta: Salemba Empat.

Basuki, A. T., \& Prawoto, N. (2016). Analisis Regresi dalam Penelitian Ekonomi \& Bisnis: Dilengkapi Aplikasi SPSS \& Eviews. Jakarta: Raja Grafindo Persada.

Chen, S., Chen, X., Cheng, Q., \& Shevlin, T. (2010). Are Family Firms More Tax Aggressive Than Non-Family Firms? Journal of Financial Economics, 91(February), 41-61. doi:

https://doi.org/10.1016/i.jfineco.200 $\underline{9.02 .003}$

Dechow, P., Sloan, R., \& Sweeney, A. (1995). Detecting Earnings Management. The Accounting Review, 70(2), 193-225. Diakses dari www.jstor.org/stable/248303

Desai, M. A., \& Dharmapala, D. (2009). Corporate Tax Avoidance and Firm Value. Review of Economics and Statistics, 91(3), 537-546. doi: https://doi.org/10.1162/rest.91.3.53 $\underline{7}$
Diawati, A. A. (2017). Analisis Pengaruh Good Corporate Governance, Karakter Eksekutif, Profitabilitas, dan Ukuran Perusahaan terhadap Tax Avoidance. Skripsi. Sekolah Tinggi Ekonomi Perbanas.

Erickson, M., Hanlon, M., \& Maydew, E. L. (2004). How Much Will Firms Pay For Earnings That Do Not Exist? Evidence of Taxes Paid On Allegedly Fraudulent Earnings. The Accounting Review, 79(2), 387-408. doi:

https://doi.org/10.2308/accr.2004.7 9.2.387

Ewert, R., \& Wagenhofer, A. (2005). Economic Effects of Tightening Accounting Standards to Restrict Earnings Management. The Accounting Review, 80(4), 11011124.

doi: https://doi.org/10.2308/accr.2005.8 0.4 .1101

Frank, M. M., Lynch, L. J., \& Rego, S. O. (2009). Tax Reporting Aggressiveness and Its Relation to Aggressive Financial Reporting. The Accounting Review, 84(2), 467496.

doi: https://doi.org/10.2308/accr.2009.8 4.2.467

Hanlon, M., \& Heitzman, S. (2010). A Review of Tax Research. Journal of Accounting and Economics, 50(2$3), \quad 127-178$. doi: https://doi.org/10.1016/j.jacceco.20 $\underline{10.09 .002}$

Hanlon, M., \& Slemrod, J. (2009). What Does Tax Aggressiveness Signal? Evidence From Stock Price Reactions to News About Tax Shelter Involvement. Journal of Public Economics, 93(1-2), 126141.

doi: https://doi.org/10.1016/j.jpubeco.20 08.09.004

Healy, P. M., \& Wahlen, J. M. (1999). A Review of the Earnings 
Management Literature and Its Implications for Standard Setting. Accounting Horizons, 13(4), 365383.

doi: https://doi.org/10.2308/acch.1999.1 3.4.365

Hutapea, D. C. (2009). Analisis Pengaruh Perbedaan Laba Akuntansi dan Laba Fiskal Terhadap Persistensi Laba, Akrual, Arus Kas dan Manajemen Laba. Tesis. Universitas Indonesia.

Investing.com. (2019). Investing.com. Diakses dari https://www.investing.com/

Kamila, P. A. (2014). Analisis Hubungan Agresivitas Pelaporan Keuangan dan Agresivitas Pajak. Finance and Banking Journal, 16(2), 228-245. Diakses dari http://journal.perbanas.id/index.php /jkp/article/download/197/21

Kementerian Keuangan Republik Indonesia. (n.d). APBN 2018. Diakses dari https://www.kemenkeu.go.id/apbn2 $\underline{018}$

Kurniasih, T. \& Sari, M. M. R. (2013). Pengaruh Return On Assets, Leverage, Corporate Governance, Ukuran Perusahaan, dan Kompensasi Rugi Fiskal pada Tax Avoidance. Buletin Studi Ekonomi, 18(1), 58-65. Diakses dari https://ojs.unud.ac.id/index.php/bse/ article/view/6160

Lennox, C., Lisowsky, P., \& Pittman, J. (2013). Tax Aggressiveness and Accounting Fraud. Journal of Accounting Research, 51(4), 739778.

doi: https://doi.org/10.1111/joar.12002

Nurhandono, F., \& Firmansyah, A. (2017). Lindung Nilai, Financial Leverage, Manajemen Laba dan Agresivitas Pajak. Jurnal Media Riset Akuntansi, Auditing \& Informasi, 17(1), 31-52. doi: http://dx.doi.org/10.25105/mraai.v1 $\underline{7 i 1.2039}$

OECD. (2013a). Action Plan on Base Erosion and Profit Shifting. OECD Publishing. doi: https://doi.org/10.1787/9789264202 $\underline{719-e n}$

(2013b). Co-operative Compliance: A Framework: From Enhanced Relationship to Cooperative Compliance. OECD Publishing. doi: https://doi.org/10.1787/9789264200 852-en

. (2015). Mandatory Disclosure Rules, Action 12-2015 Final Report, OECD/G20 Base Erosion, and Profit Shifting Project. OECD Publishing. doi:

https://doi.org/10.1787/9789264241 442-en

Prawira, I.F.A. (2017). Corporate governance and Tax Aggressiveness, an evidence on Manufacturing Companies in Indonesia. International Journal of Accounting and Economics Studies, 5(2), 134-140. doi: https://doi.org/10.14419/ijaes.v5i2. $\underline{8132}$

(2017). How The Executive Characteristics Affect The Property, and Real Estate Companies do Tax Aggressiveness?. Account and Financial Management Journal, 2(11), 1126-1131. Diakses dari http://everant.org/index.php/afmjh/a rticle/view/198/192

Prawira, I. F. A., \& Setiawan, Y. (2018). Tax Aggressiveness and Accounting Fraud Practice: An Evidence in ASEAN Countries. International Journal of Multidisciplinary Education and Research, 3(1), 5-10. Diakses dari http://www.educationjournal.in/do wnload/263/2-6-38-331.pdf 
Rego, S. O. (2003). Tax Avoidance Activities of U.S. Multinational Firms. Contemporary Accounting Research, 20(4), 805-833. Diakses dari

https://ssrn.com/abstract $=427600$

Sartono, Agus. (2008). Manajemen Keuangan Teori, dan Aplikasi. Yogyakarta: BPFE Yogyakarta.

Sekaran, U. (2014). Metodologi Penelitian untuk Bisnis (4th ed.). Jakarta: Salemba Empat.
Sugiyono. (2018). Metode Penelitian Kuantitatif, Kualitatif, dan $R \& D$. Bandung: Alfabeta.

Triyanto, H. U., \& Zulvina, S. (2017). Analisis Perumusan Kebijakan Mandatory Disclosure Rules Sebagai Alternatif Dalam Mengatasi Praktik Penghindaran Pajak Di Indonesia. Jurnal Pajak Indonesia, 1(1), 1-10. Diakses dari http://jurnal.pknstan.ac.id/index.php /JPI/article/view/163/133 